\title{
Small Cell Component Present
}

National Cancer Institute

\section{Source}

National Cancer Institute. Small Cell Component Present. NCI Thesaurus. Code C96361.

A morphologic finding that refers to the presence of a small cell component in a cellular infiltrate. 